\title{
Visualisation of Animals by Children: How Do They See Birds?
}

Sue Dale Tunnicliffe ${ }^{1}$

$\approx$ Children learn to recognise animals from their earliest years through actual sightings in their own observations of their world, but also through second-hand representations in various forms of media. Young learners begin with a template specimen to which they refer when they see another animal that resembles it, naming the animal accordingly. Gradually, they learn to distinguish members of the subordinate category - bird in the case of the present paper - into subcategories. Accessing their mental model through drawings is one means of discerning their interpretation of both phyla and species. If children of increasing ages are studied, a rationale for the understanding of a such concepts may be forthcoming. The present study investigated children from 6 years to 14 years though interviews, as well as through the drawings on which the paper focuses. As children mature, they observe more and more details about the birds that they see, thus increasing their knowledge not from school but from their own observations outside school.

Keywords: Children's drawings, Children's understanding of birds

1 Lecturer in Science Education, Institute of Education, University of London, England UK lady.tunnicliffe@me.com 


\section{Vizualizacija živali pri otrocih: kako vidijo ptiče?}

Sue Dale Tunnicliffe

$\propto$ Otroci se od majhnega učijo prepoznavati živali, ko jih dejansko vidijo, kadar opazujejo svet okrog sebe oz. v različnih medijih. Ti mladi učenci najprej razvijejo vzorčni model neke živali, ki si ga prikličejo, ko vidijo podobno žival in jo poimenujejo po tem modelu. Postopoma se otroci naučijo razvrščati predstavnike te kategorije organizmov - v tem primeru ptiče - v podkategorije. Ena izmed možnosti raziskovanja otrokove interpretacije debla in vrste kot taksonomske kategorije je uporaba risbe, s katerimi otroci prikažejo svoje mentalne modele. Z raziskovanjem mentalnih modelov različno starih učencev lahko ugotovimo, kako se s starostjo učencev razvijajo tovrstni pojmi. Ta raziskava je zajela učence, stare od 6 do 14 let, podatki pa so bili zbrani z intervjuji in risbami učencev, na katere se prispevek osredinja. Ko učenci odraščajo, opazijo vse več podrobnosti v povezavi s ptiči, kar vpliva na boljše znanje o teh organizmih, to pa ni povezano z znanjem, pridobljenim v šoli, ampak z lastnim opazovanjem zunaj šole.

Ključne besede: risbe učencev, razumevanje pojmov o ptičih 


\section{Introduction}

Children see animals in their everyday lives. They notice them in the real world and often in the media, both electronic and paper forms, as well as in representations in household items such as wallpaper for children and soft toys (Tunnicliffe, Gatt, Agius, \& Pizzuto, 2008). When they see live animals they identify striking features of their anatomy and behaviour, whether they are observed in everyday life (Patrick \& Tunnicliffe, 2011) or in a zoo or field centre, for instance (Tunnicliffe, 2000). When looking at animals as exhibits (Tunnicliffe, Lucas, \& Osborne, 1997) children remark out loud about the salient features of the animals they see, such as a leg, a shape, bits that stick out and colour, as well as any behaviours observed at the time. Thus, from their earliest years, children gain knowledge and experience of the animals in the everyday environment where the children live and attend school. Indeed, this knowledge is not necessarily gained from formal education (Tunnicliffe \& Reiss, 1999a, 2001), which may serve simply to amplify and extend existing knowledge. However, pupils in English state schools are taught about the basic grouping of organisms in their formal schooling. A useful point to bear in mind when considering formal teaching strategies for children to learn more about animals is that school science generally assumes that for any scientific issue there is a single valid scientific conception. Other ideas that do not agree with the accepted conception are alternative conceptions, and are often called misconceptions. Driver, Squires, Rushworth and Wood-Robinson (1994) refer to personal knowledge that has been acquired through the child's own life experiences, both real and virtual, as alternative conceptions.

\section{Theoretical background}

Visualisation in science education embraces many different aspects of the concept, ranging from mental models and their formation, which are considered central to science learning, to recognising $2 \mathrm{D}$ and ${ }_{3} \mathrm{D}$ representations, which can show aspects of the learner's grasp of concepts (Gilbert, 2005). As Gilbert points out, the interpretation of visualisation varies between researchers. In the present paper, visualisation is considered as visual imagery shown through drawings but in conjunction with personal knowledge construction expressed in words about the phenomenon, in this case the bird that is commonly referred to as a pigeon.

Looking after animals influences children's understanding of the biology of animals (Inagaki, 1990). The knowledge of animals held by children has 
been explored by several researchers. For instance, Hantano and Inagaki (1997) showed that children's biological understanding is acquired in their early years through daily experiences. Amongst the variety of animals with which children come into contact, birds have been a frequent species of study. Randler (2009) found that the knowledge of a variety of species of bird increased with age in primary children after a particular method of teaching. Prokop, Kubalto and Francovicova (2008) investigated children's concepts about birds, investigating the knowledge and attitudes of Slovak pupils about this vertebrate class. Birds are not regarded as dangerous. Hens and chickens were the only birds mentioned in Cardak's study (Cardak, 2009) of Turkish students' ideas about dangerous animals, and these were only referred to three times, which is an insignificant number. However, Prokop and Tunnicliffe (2010) found that children knew more about unpopular animals, and in English society pigeons are certainly unpopular.

A great deal has been written about visualisation in science education, but it is confined to the physical sciences and not the natural sciences (Gilbert, 2005). When teachers or researchers ask subjects about their understandings of anything, subjects respond by presenting representations (Bruner, 1964). Such representations may be words or mathematical symbols, drawings, physical constructions or even gestures. When these representations are made in the public domain for anyone to observe they may be referred to as expressed models (Buckley, Boulter, \& Gilbert, 1997). The only way for a researcher to understand the mental model held by the subjects, in this case children, is to observe one or more of their expressed models. Although there are limitations to studying drawings executed by children - their inability to draw what they want to due to a lack of skill, and what seems like unintelligible marks to the researcher often being able to be explained by the child in an interview - drawings are nonetheless still a means of accessing mental models.

Drawing is easier than writing for many children, particularly very young children, and making representations on paper is a stage in the development of a normal child, when they are in the iconic mode and progress to the symbolic mode (Bradford, 2012). The basic hypothesis of Luquet, (1921, cited by Krampen, 1991) is that, in the development of drawings executed by young children, there is a gradual tendency toward realism. Thus, the final aim of drawing would be a realistic translation of the visual properties of objects into graphics.

According to Luquet, in drawings children do not directly transmit the characteristics of objects, that is, they do not simply copy them, but rather they put on paper the features of internal models of objects that they observe. Luquet proposed five phases in drawing development: (1) Scribbling (typical at 
ages 2-3 years); (2) Fortuitous realism (the discovery of similarities between certain features of scribbles and objects in reality, which begins to emerge at ages 3-4 years); (3) Failed realism (synthetic incapacity, as seen in drawings by children of 4-5 years of age); (4) Intellectual realism (the child draws what is known about reality, a stage that is generally from 5-8 years); (5) Visual realism (in this stage, which occurs between ages $8-12$, the child draws what is visible only from a certain point of view in reality, i.e., from a certain perspective).

Symington, Boundy, Radford and Walton (1981) proposed three stages, which involve children acquiring both the skill and the conceptual basis to produce recognisable pictures. First of all, they proposed a scribbling phase, when children are able to actually hold a writing implement and successfully mark the paper. In this phase, the child produces scribbles that to them may represent the organism that they have been requested to draw, but to others hardly bears any resemblance to the animal. Developing from this is scribble symbolism, with the output on paper being used more as a symbol of the child's idea of the object than to show what it is really like. In this stage, the salient features such as the head and torso of a human are drawn. The last phase, visual realism, is where the object and the picture bear a closer and more detailed resemblance.

The mental models drawn upon by the child when drawing an animal are representations of an object, or an event, that are formed by the process of modelling, as pointed out by Duit and Glynn (1996), who state that the process of forming and constructing models is a mental activity of an individual or group. The models are personal and unique, based on the child's own knowledge of the phenomenon, that is, animals seen in the everyday environment, museums, nature parks and zoos, as well as in representations in books and electronic media, in contrast to conceptual knowledge acquired through formal and informal education. The conceptual knowledge of the formal curriculum includes the taxonomic position of the species, its criteria attributes, and the intension and extension of the species. There is, however, a relationship between the mental model, the animal or human viewed (the trigger or real object) and what the child says.

Brooks (2009) suggests that through visualisation and expression through the representation of ideas, the essence that children have understood is focused in consciousness early on; thus, she suggests that a drawing is an externalisation of a concept or idea. Drawings are products of the drawer's imagination (Reiss, Boulter, \& Tunnicliffe, 2007) and memory as expressed models (Gilbert \& Boulter, 2000). As Brooks (2009) points out, drawings and visualisations can also help young children to shift from everyday or spontaneous concepts to more scientific concepts. Their construction also enables children 
to come to terms with spatial visualisations, interpretations, orientations and relations, and Brooks claims that when children are able to create visual representations of their ideas they are more able to work at an achieved cognitive level. There is, of course, always the proviso that the children must be capable of achieving the technical and manipulative skills of drawing. Personal experience of interviewing children with their previously constructed drawing indicates that knowledge of the subject, e.g., the organs in the human body, can be greater than the understanding indicated by the drawing, as although the child constructing the drawing may have found a particular feature too difficult to represent, he or she was able to describe the phenomenon in an interview (Tunnicliffe, Boulter, \& Reiss, 2011).

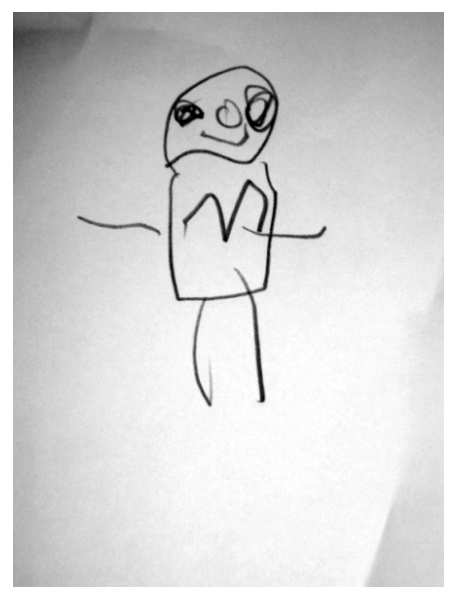

Figure 1: A self-portrait by Luc aged 4 .

Influenced by what they see, children abstract out the salient features of the human form, as in the self-portrait by a four-year-old boy (Figure 1). In the early years, children have an innate desire to draw even before they can articulate a description. For these young children, drawing is an effective form of conjunction, provided that whoever reads the drawing can interpret that which they draw. The 'tadpole man' of Figure 1 is a frequently cited example of this, where children draw a body, a head and stick limbs.

It is already known that knowledge of the internal organs of humans and other organisms can, to a certain extent, be elicited through analysing drawings constructed by children of differing and increasing ages according to a protocol. This includes work on the skeletons and internal organs of vertebrates (Tunnicliffe and Reiss, 1999b; Prokop et al., 2008). 


\section{Research questions}

The research questions were:

1) What do children know about a common everyday species of bird, the pigeon, (Columba palumbus)?

2) How do children visualise a common species in words and in a drawing?

3) To what extent are drawings of birds similar when drawn by children of increasing age, and is there an identifiable progression in skill of representation?

Answers to these particular questions were sought in data collected from a wider study of six frequently found organisms and two natural phenomena in the everyday environment.

\section{Method}

\section{Participants and location}

School children drawn from five classes of Year 1 children (aged 5-6 years), Year 4 children (aged 9-10 years) and Year 9 children (aged 3-15 years) were interviewed and asked to draw an environmental scenario that included birds. This work was carried out as part of a larger study (Tunnicliffe et al., 2011). The children attended a variety of schools in Southern England, including London, and were from a range of ethnic and first-language backgrounds.

\section{Instruments}

The cues used to initiate dialogues prior to a visit to a field site, zoo, museum or field centre were either a black and white reduced-image line drawing, a colour photograph with a context, or the word 'pigeon'. After the field visit, dialogues were initiated by using a word - in the case of the present paper, the word 'pigeon'.

\section{Research design}

The children were interviewed and cued to talk about what they knew about pigeons. The interviews were transcribed and analysed according to a rubric of levels of organisation (see Tunnicliffe et al., 2011). The drawings of the environment including all of the items discussed were collected after the final interviews and analysed by the author using a 'look re-look' process to identify 
the features of the birds that were portrayed. Details of the particular criteria used are given with the findings below.

\section{Results}

The data collected revealed that older pupils in secondary school had more specific knowledge of pigeon characteristics, and that this knowledge was based on observations of behaviours rather than on formal teaching. Many of the older children reported that pigeons are kind of a grey colour. One respondent remarked, 'They have silver and green wings and are shiny and that you can get white pigeons which are called doves. Erm, they are birds they fly.'

Biological information supplied by the pupils was not always accurate; they demonstrated biological knowledge from their own observations and listed what they regarded as the criteria attributes of 'pigeonness', by which they meant birds in general. The features of birds exemplified by pigeons are beaks, colour, wings and legs, with older pupils also mentioning feathers. These are the features represented in the drawings constructed by the pupils.

When interviewed with the one of the cues - a colour photograph, a black and white drawing or the word (Pigeon) - the children talked about the specific behaviour of pigeons that they had observed as part of the essence of being a pigeon, as well as basic anatomical features. The justification for allocating pigeon to a bird was given by one six-year-old boy as, 'Because its got wings and two legs, a pigeon is a bird, err. They are quite big and have got err... grey feathers.' An older primary school pupil said, 'I normally see them flying around the sky in my back garden.' Another remarked, '...it's a bird because it flies.' A girl who attended a Year 9 class reported, "Um, when they make a noise it's like a too-wit-too-woo sort of noise, a bit like an owl. Um, there are loads of them in London.' Another of the secondary school children informed us, '... they make nests. They like to sit on top of our school roof, they reproduce, they can fly.' A sixyear-old boy talked about pigeon racing characteristics and how if a male and female pigeon were put together they mated. In her interview, a fourteen-yearold girl was asked what they ate; she responded, '...worms they are supposed to but they don't.' The same girl went on to remark about a specific behaviour - flying - and then talked about a characteristic anatomical feature of birds, ... well they are quite aerodynamic so that when they fly they are smooth, urhm, they have got beaks for clinging onto tree branches and claws. That's about it.'

In terms of human influences, a number of children were familiar with the uses of pigeons in our society, such as pigeon racing, and had obtained knowledge from their family. A ten-year-old boy attending Year 5 reported that 
his father had kept pigeons, not for racing but for sending notes, while a sixyear-old boy attending Year 1 reported, 'I know all about pigeons 'cos my granddad's got them.'

Pigeons were regarded as urban inhabitants. A ten-year-old boy attending Year 5 reported that he saw pigeons in lots of places, including at football matches in London, where they walked on the pitch. Other children of all ages talked about seeing pigeons in their local town congregating outside the fastfood shops to eat any potato chips and other food debris on the pavement. Some older pupils did, however, know about the behaviour of worm-eating birds in stamping on the ground to simulate the vibration of rain, to which earthworms respond by emerging from their burrows.

Children had noticed pigeons themselves in their local town, as one Year 5 pupil reported: 'It's got wings and two legs and likes nicking your food up town when you go to buy fish and chips. When you drop one they always go running to it!' Other human- pigeon interactions mentioned included pigeons eating food scraps in towns, and the fact that they sometimes carry disease. The secondary pupils (Year 9, older than 11 years) held the perception that pigeons were dirty; 'rats of the air' was the phrase used by one girl.

\section{Representing pigeons - the drawings}

The pigeon is represented in several ways in drawings, and there are a range of ways in which children depict reality (Reiss et al., 2007). The first basis of the analysis of the drawings obtained, undertaken through inspection, was the layout, an exhibit-type picture representation with the organisms placed with a relationship to one another, together representing where they may be found naturally. For instance, trees were always drawn coming from the ground where the grass was drawn. A few children drew isolated organisms with no link to one another. Secondly, the way in which the pigeon was represented was examined. The representations included as a symbolic ' $V$ ' shape, just an outline of a bird, an outline with basic features, and an artistic realistic image. Thirdly, there was an assessment of whether the pupils had shown any behaviours of the pigeon in their drawing. Finally, a record was made of whether more than one pigeon had been drawn and whether another type of bird was included in the drawing. 


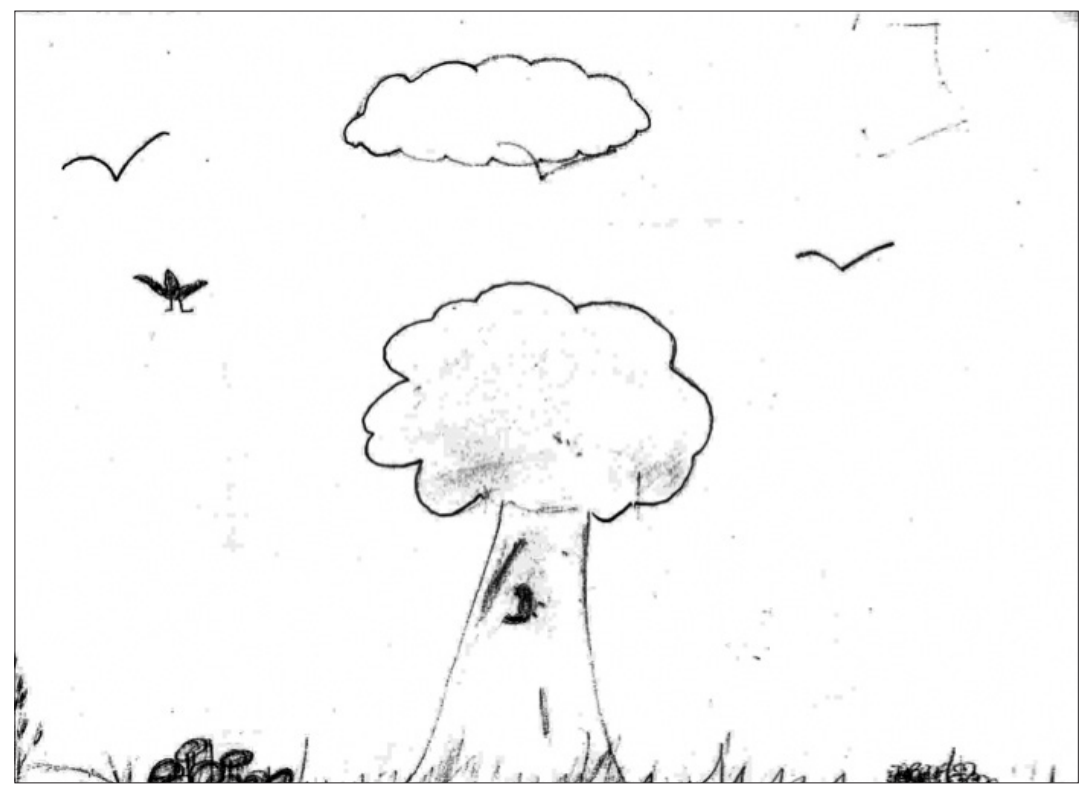

Figure 2: Drawn by a Year 9 pupil, the picture shows the iconic ' $\mathrm{V}$ ' drawn to represent birds, as well as an outline drawing of a bird flying.

In the expressed model of pigeons revealed through the drawings, only solitary birds were drawn. The bird was not placed in the urban context in which the children reported seeing the birds for themselves and was shown exhibiting behaviour such as flying, sitting in a tree or standing on the ground. Interestingly, although ecology teaching in England stresses food chains and food webs, feeding relationships were not depicted in the drawings.

The data presented in Figure 2 reveal how the pigeon is depicted, whether the bird is presented as part of a drawing, even if the image drawn shows a known behaviour such as walking or flying but with no relationship to another object. Young children abstract out salient features - a round body, two legs, two wings, a head and a beak - similar to the abstraction of main features shown by child's drawing of a human in Figure 1. 
Table 1: Analysis of drawings of natural objects, one of which was a pigeon, by 24 pupils, with some pupils drawing several representations.

\begin{tabular}{|c|c|c|c|c|}
\hline Feature in drawing & $\begin{array}{c}\text { Year } 1 \\
\text { (6 years) }\end{array}$ & $\begin{array}{c}\text { Year } 5 \\
(10 \text { years })\end{array}$ & $\begin{array}{c}\text { Year } 9 \\
\text { (14 years) }\end{array}$ & TOTAL \\
\hline Drawing black and white & 6 & 0 & 7 & 13 \\
\hline Drawing in colour & 0 & 6 & 5 & 11 \\
\hline List drawing & 3 & 1 & 7 & 11 \\
\hline Exhibit style & 3 & 5 & 5 & 13 \\
\hline Symbolic representation & & & 2 & 2 \\
\hline Outline & 1 & 1 & & 2 \\
\hline $\begin{array}{l}\text { Basic features, beak, legs, } \\
\text { body, wings }\end{array}$ & 1 & 6 & 10 & 17 \\
\hline Artistic image & & & 1 & 1 \\
\hline $\begin{array}{l}\text { Behaviour shown, e.g., } \\
\text { walking, flying }\end{array}$ & 7 & 8 & 17 & 32 \\
\hline One plus drawn & 1 & 1 & 3 & 5 \\
\hline No bird & 2 & & & \\
\hline $\begin{array}{l}\text { Other type of bird, e.g., } \\
\text { duck }\end{array}$ & 3 & & & 3 \\
\hline
\end{tabular}

Alternatively, the target object is shown as an exhibit-type illustration in the manner of a natural history diorama, including all of the specimens being studied and shown with some type of relationship between them, as well as portraying their behaviours known to the pupil, such as a tree growing upright, grass on the ground near the tree and the bird being portrayed involved in a known behaviour.

Table 2: The behaviours shown in the drawings of the pupils.

\begin{tabular}{|l|c|c|c|c|}
\hline Behaviours illustrated & $\begin{array}{c}\text { Year } \mathbf{1} \\
\text { (6 years) }\end{array}$ & $\begin{array}{c}\text { Year 5 } \\
\text { (10 years) }\end{array}$ & $\begin{array}{c}\text { Year 9 } \\
\text { (14 years) }\end{array}$ & TOTAL \\
\hline Walking on ground & 3 & 6 & 12 & 21 \\
\hline Flying & 2 & 1 & 5 & 8 \\
\hline Sitting in tree & 2 & 1 & 0 & 3 \\
\hline Total & 7 & 8 & 17 & 32 \\
\hline $\begin{array}{l}\text { Five drawings had more } \\
\text { than one bird }\end{array}$ & 1 & 1 & & \\
\hline
\end{tabular}




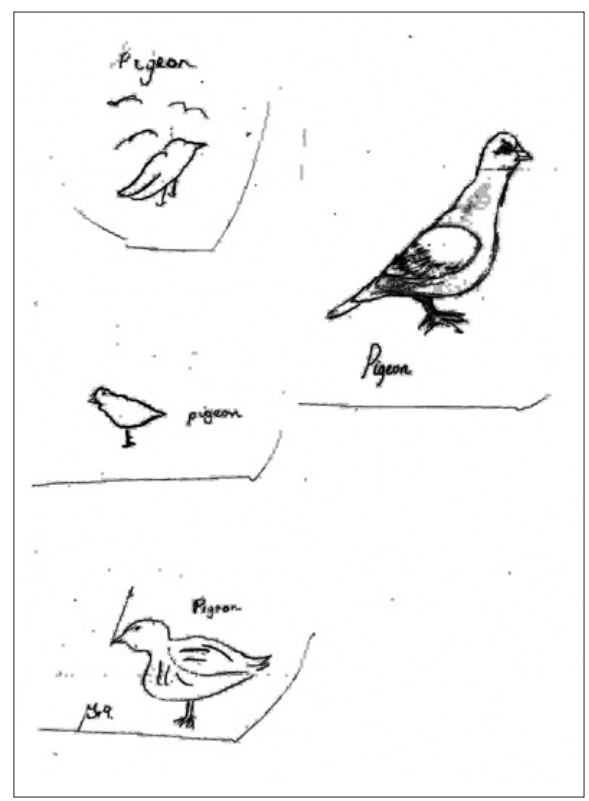

Figure 3: The range of ways in which pigeons were represented. Three levels of interpretation - outline, symbols and realism.

An example of behaviour recalled from having been told or seen in cartoons was the fact that birds eat worms, a behaviour that was cited by some children. Some interviewees mentioned this phenomenon but did not draw it. The iconic representation of a pigeon ranged from a simple ' $\mathrm{V}$ ' symbol (Figure 2), through a basic outline, to an outline with a more accurate representational drawing showing the criteria attributes that the pupils considered to be those of 'birdness', e.g., two legs, a slightly torpedo-shaped body, a beak at the front of the head, and wings, similar to how the 'humaneness' features are shown in Figure 1. Indeed, these attributes are those to which the pupils referred in their interviews when describing how they would know that a pigeon is a pigeon. Such features are, in fact, bird characteristics of the super ordinate category bird, and are not specific to 'pigeon'. For example, one of the Year 5 pupils said, 'It has wings, a beak and legs.' Pupils did not mention feathers in their list of criteria features, nor, with the exception of the artistic rendering in one drawing (Figure 3), did they draw them. Two Year 5 pupils used colour. The drawings illustrated basic anatomical defining features, such as two wings, two legs, feathers and a beak, as well as behaviour such as flying or walking on the ground (or water!!!). Year 9 pupils executed drawings using colour and were the interviewees who composed more realistic drawings (although not all of them, by any 
means). This phenomenon was noted by Luquet (1927 translated 2001), who commented that adults are committed to visual realism whereas children are proponents of a cerebral analytic process.

A few drawings showed the bird exhibiting behaviour such as flying, walking on the ground or sitting in a tree, while a few offered two levels of interpretation: symbols and basic features (Figure 3 ).

Occasionally, an artistic rendering was made as if drawn from life (Figure 3). Several other fourteen-year-old pupils, not included in the target sample, drew almost photographic likenesses of a bird in a detailed drawing forming a pictorial composition. We did not interview the pupils with their drawings, so we were unable to explore certain features, such as the object in the two birds drawn in Figure 4. However, several of the pupils talked about pigeon babies and eggs, so the circular object drawn in the body of the birds could be those images. A few pupils drew individual drawings of the objects represented in absolute isolation with no context, and one drew his pigeon next to a pond.

Other drawings placed the objects in a rural or garden setting, without buildings, with some interrelationship between the objects (Reiss et al., 2007). Two of the Year 1 pupils drew two birds, one in a tree and one on the ground, while two Year 5 pupils also depicted two birds. One drawing by a Year 1 child showed a bird looking rather like the Concorde aircraft on the ground, and another bird, possibly a representation of a duck, walking on the surface of a pond.

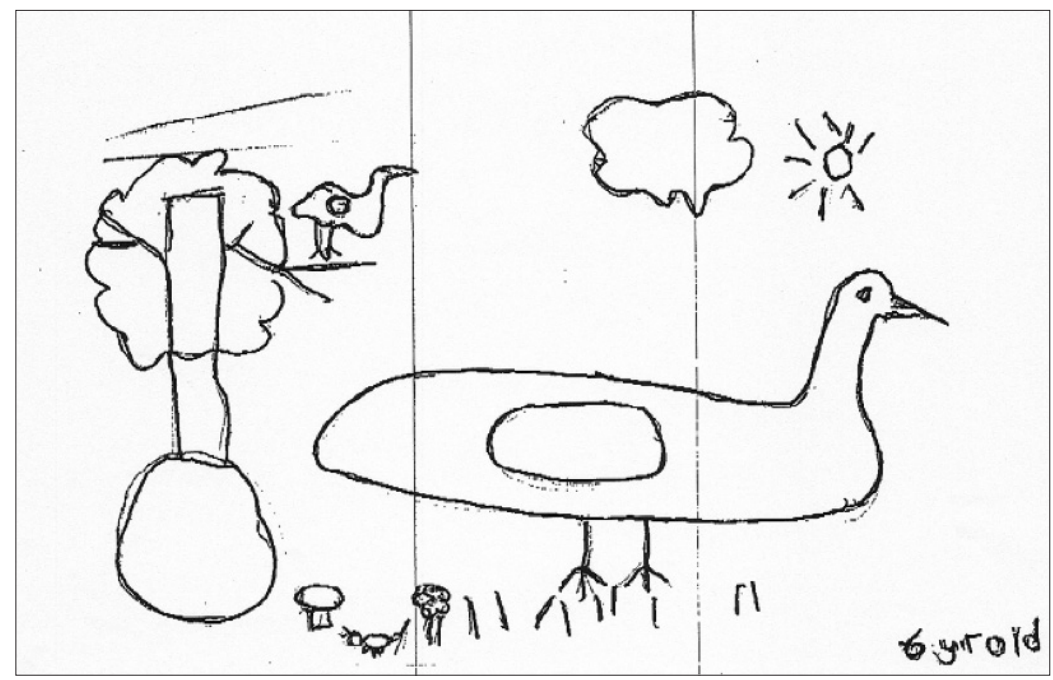

Figure 4: Birds with "eggs" inside. 
The majority of the Year 9 drawings illustrated the objects separately in the manner of a key. Three drawings were executed as a composition. Several of the birds were depicted artistically in a lifelike manner. Apart from the artistic representations drawn by a fourteen-year-old, the drawings were simple outlines.

The results show that a study of everyday animals based on interviews and drawings (done on separate occasions) reveals not only biological knowledge but also widespread social and some cultural beliefs and understandings. The systems analysis revealed personal experiences that were important to the speaker in the form of narrative, connected with the probe word. The most detail was given about the anatomical features of the pigeon, such as feathers and a beak. The pupils knew that pigeons live on the ground or in trees and that they can fly. Mainly older pupils were conversant with the public understanding of the pest and vermin role of pigeons in our society, while some pupils had knowledge of the use of pigeons by humans, although the eating of pigeons was not mentioned.

\section{Discussion}

Children thus have a considerable knowledge of the living world immediately around them from personal first-hand observations, both real and virtual. We know that children explain phenomena in other animals by using themselves as their reference (Carey, 1985). In the present study, the pupils extrapolated from their knowledge of themselves, or the behaviour of birds they knew, to the species under consideration. These ideas may be reinforced by cartoons and popular stories, such as the concept that all birds eat worms in the interview mentioned above. The children in the studies reported here had made observations and had experiences of many of the objects through activities with their families and school. School grounds emerged as an important influence in a number of the interviews. In research in which children were interviewed in the presence of whole, live plant specimens and preserved, whole, animal specimens (Tunnicliffe \& Reiss, 1999a, 1999b), it was also evident that home influences were most important in providing the children with their understandings of the organisms. The schools described in the present paper are in suburban settings, and it would be interesting to compare the results obtained with those from schools in urban and rural settings. From an early age, children are able to abstract the salient features that make up the concept 'bird' from their own observations, both real and second hand through cartoons and other media.

Perhaps more attention should be paid to producing both formal and informal school activities that draw on this rich knowledge of how humans 
interact with the natural world. School grounds could be used for such observations. The revealed importance of gardens and school grounds suggests that teachers should be alert to the interests that many pupils still have in horticulture and gardening.

Most pupils described where the pigeon they were asked about had been seen, and thus could be found. The places mentioned were generally places of social interaction for human beings in their everyday lives, not isolated wildernesses. They included parks, gardens, school fields and football pitches, streets or squares in towns, their homes and their immediate neighbourhood. Venues do not need to be to distant pristine habitats in order to be memorable to children. In fact, linking school science, especially science for preschool and primary children (3-11 years in England), with pupils' memories of local places may be an important way to start to focus on biological learning, either inside the classroom or when planning visits, rather than focusing on exotic mega fauna with a visit to the zoos and creating rain forest simulations in classrooms, as so many English schools do. One striking conclusion from the research reported here is the importance of popular myth in children's knowledge. The myths that children knew regarding many of the objects had clearly been strongly influenced by books, TV programmes and cartoons of birds pulling up worms, a behaviour that pigeons do not display.

\section{Conclusions}

Educators need to be aware of the separate domains used by learners in interpreting biological phenomena. Moreover, the educator often introduces pupils to organisms by using a key word, thus eliciting the pupil's existing mental model. This is not necessarily the same for all pupils, as it depends on their interest and experiences influenced by their immediate sociocultural environment, as well as by the natural world. It may also reveal understandings gained from everyday experiences and from children's media and myths, as well as popular public understanding about the phenomenon, in this case a commonly seen animal. Thus, if meaningful learning by pupils is to be constructed, biological concepts cannot be taught in isolation from an awareness and knowledge of other influences that contribute to a child's understanding. As children develop, they become more involved in feelings, and, it seems, in the possible influences of themselves and others on their environment.

The data obtained in the present study indicate that specific species are not taught in English schools. General shared features of birds are acquired from everyday observations in the early years: beaks, two wings, two legs and 
feathers, as well as characteristic behaviours, such as flying and eating food debris. Specialist knowledge, such as carrier pigeons, racing pigeons and breeding birds, was acquired first hand from another persons, often a family member.

What is clear from these studies is that school teaching and the learning opportunities provided at school do not have as greater influence on how children understand objects in the natural environment as we might perhaps think, especially in the case of younger children. Both formal and informal educators could learn by observing, speaking with and listening to pupils about what they experience in their own worlds, what interests them and what aspects of the natural world they have learnt about through books and other media and influences. Such baseline knowledge of learners should be the basis for teaching these ideas, and should form foundations on which teachers and curriculum planners formulate curricula and assessments.

Note: Part of this paper was presented orally at the BERA conference at the Institute of Education, London in September 2007.

\section{References}

Bradford, H. (2012). Appropriate Environments for Children Under 3. England: A David Fulton Book, Routledge, p. 22.

Brooks, M. (2009). Drawing, Visualization and Young Children's Explorations of Big Ideas.

International Journal of Science Education, 31(3), 319-343.

Bruner, J. S. (1964). The course of cognitive growth. American Psychologist, 19(1), 1-15

Buckley, B., Boulter, C., \& Gilbert, J. K. (1997). Towards a typology of models for science education.

In J. Gilbert (Ed.). Exploring Models and Modelling in Science and Technology Education (pp. 90-105).

Reading: University of Reading.

Cardak, O. (2009). Students' ideas about dangerous animals. Asia-Pacific Forum on Science Learning and Teaching, 10(2), 1-15.

Cardak, O. (2009). Science students' misconceptions about birds. Scientific Research and Essay, 4(12), $1518-1522$.

Duit, R., \& Glynn, S. (1996). Mental modelling. In G. Welford, J. Osborne, \& P. Scott (Eds.), Research in science education in Europe (pp. 166-176). London: Falmer.

Driver, R., Squires, A., Rushworth, P., \& Wood-Robinson, V. (1994). Making sense of secondary science. Research into children's ideas. London: Collins Educational.

Gilbert, J. K. (2005). Visualization a meta-cognitive skill in Science and Science Education. In J. K. Gilbert (Ed.), Visualization in Science education (pp.9-27). Dordrecht: Springer

Gilbert, J. K., \& Boulter, C. (200o). Developing Models in Science Education. Dordrecht: Kluwer. Hatano, G., \& Inagaki, K. (1997). Qualitative changes in intuitive biology. European Journal of 
Psychology of Education, 12(1), 111-130.

Inagaki, K. (1990). The effects of raising animals on children's biological knowledge. British Journal of Developmental Psychology, 8(1), 119-129.

Krampen, M. (1991). Children's drawings: iconic coding of the environment. New York: Plenum Press. Luquet, G.-H. (2001 [1927]). Children's Drawings (Le Dessin Enfantin), trans. A. Costall. London: Free Association Books.

Patrick, P. \& Tunnicliffe, S. D. (2011). What Plants and Animals Do Early Childhood and Primary Students' Name? Where Do They See Them?. Journal of Science Education Technology, 20(5), 630-642. Prokop, P., \& Tunnicliffe, S. D. (2010). Effects of keeping pets on children's attitudes toward popular and unpopular animals. Anthrozoös, 23(1), 21-35.

Prokop, P., Kubalto, M. \& Francovicova, J. (2008). Slovakian Pupils' knowledge of, and Attitudes toward, Birds. Anthrozoös, 21(3), 221-235.

Randler, C. (2009). Learning About Bird Species on the Primary Level. Journal of Science Education and Technology, 18(2), 138-145.

Reiss, M. J., Boulter, C., \& Tunnicliffe, S. D. (2007). Seeing the natural world: A tension between pupils' diverse conceptions as revealed by their visual representations and monolithic science lessons. Visual Communication, 6(1), 95-110

Symington, D. J., Boundy, K., Radford, T., \& Walton, J. (1991). Children's drawings of natural phenomena. Research in Science Education, 11(1), 44-51.

Tunnicliffe, S. D. (2000). Developing Field Visits for Facts and Feelings. Field Studies, 9(3), 549-560. Tunnicliffe, S. D., Lucas, A. M., \& Osborne, J. F. (1997). School visits to zoos and museums: A missed educational opportunity? International Journal of Science Education, 19(9), 1039-1056.

Tunnicliffe S. D. \& Reiss M. J. (1999a). Building a model of the environment: how do children see animals?. Journal of Biological Education, 33(3), 142-148.

Tunnicliffe, S. D. \& Reiss, M. J. (1999b). Student's understandings about animal skeletons. International Journal of Science Education, 21(11), 1187-1200.

Tunnicliffe, S. D., \& Reiss, M. J. (2001). What's inside bodies? Learning about skeletons and other organ systems of vertebrate animals. IOSTE, Science and technology education: preparing for future citizens, 29 April - 2 May 2001, Paralimni, Cyprus, Vol. 2, 84-94.

Tunnicliffe, S. D., \& Reiss, M. J. (1999). Building a model of the environment: How do children see animals? Journal of Biological Education, 33(3), 142-148.

Tunnicliffe, S. D, Gatt, S., Agius, C., \& Pizzuto, S. A. (2008). Animals in the lives of young Maltese children. Eurasia Journal of Mathematics, Science \& Technology. 4(3), 215-221.

Tunnicliffe, S. D., Boulter, C. J., \& Reiss, M. J. (2011). Getting children to talk about what they know of the natural world. Primary Science. 119, 24-26. 


\section{Biographical note}

Sue Dale Tunnicliffe, Dr., an expert on children in zoos and has published widely, she is graduated in zoology and has specialised in education, a qualified teacher, holds a $\mathrm{PhD}$ from King's College. Now a researcher/part time lecturer at the Institute of Education, she set up and run an advisory team in primary science and technology, then was Head of Education at the Zoological Society of London and has worked part time in a historical museum as science adviser and as an education consultant at the BBC. She has worked as a researcher and lecturer at Cambridge and Winchester Universities. 